\title{
Technical and economic viability of cowpea co-inoculated with Azospirillum brasilense and Bradyrhizobium spp. and nitrogen doses
}

\author{
Fernando S. Galindo ${ }^{1}$, Marcelo C. M. Teixeira Filho ${ }^{1}$, Edson C. da Silva ${ }^{2}$, Salatiér Buzetti ${ }^{1}$, \\ Guilherme C. Fernandes ${ }^{1} \&$ Willian L. Rodrigues ${ }^{1}$
}

${ }^{1}$ Universidade Estadual Paulista "Júlio de Mesquita Filho"/Faculdade de Engenharia de Ilha Solteira. Ilha Solteira, SP, Brasil. E-mail: fs.galindo@yahoo.com.br
(Corresponding author) - ORCID: 0000-0001-5118-7459; mcm.teixeira-filho@unesp.br - ORCID: 0000-0003-2303-3465; sbuzetti@agr.feis.unesp.br - ORCID:
0000-0003-2569-4750; guilherme.carlos.fernandes@gmail.com - ORCID: 0000-0002-9346-9873; willianrodrigues53@gmail.com - ORCID:0000-0002-3826-5915
${ }^{2}$ Instituto Federal Goiano/Campus de Rio Verde. Rio Verde, GO, Brasil. E-mail: edsoncabralsilva@gmail.com - ORCID: 0000-0002-1813-490X

\begin{abstract}
Biological nitrogen fixation efficiency can be increased by co-inoculation with Bradyrhizobium spp. and Azospirillum brasilense, allowing even greater uptake of water and nutrients, leading to higher yields and enabling the insertion of unusual crops, such as cowpea (Vigna unguiculata L. Walp.), in the agricultural production system in the Cerrado region of Brazil. Thus, this study aimed to evaluate the technical and economic viability of cowpea in the Cerrado region, as a function of $\mathrm{N}$ doses and co-inoculation of seeds with Azospirillum brasilense and Bradyrhizobium. The study was carried out in a no-tillage system in Selvíria, MS, Brazil. The experimental design was a randomized block design, with four repetitions, arranged in a $3 \times 5$ factorial scheme, corresponding to three types of inoculation (without inoculation - control, with two strains of Bradyrhizobium spp. SEMIA 6462 and SEMIA 6463 - the conventional inoculation of cowpea, and these two strains of Bradyrhizobium spp. plus A. brasilense strains Ab-V5 and Ab-V6); and five N doses (0, 20, 40, 80 and $160 \mathrm{~kg} \mathrm{ha}^{-1}$ ), as urea, applied as topdressing. The following evaluations were performed: grain yield, total operating cost, effective operating cost, gross revenue, operating profit, profitability index, equilibrium price and equilibrium yield. Co-inoculation with $A$. brasilense increases cowpea grain yield, which makes cowpea production in the Cerrado region of Brazil technically and economically viable, without the need to apply $\mathrm{N}$ fertilizers in topdressing.
\end{abstract}

Key words: Vigna unguiculata, plant growth-promoting bacteria, biological nitrogen fixation, total operating cost, famers profit

\section{Viabilidade técnica e econômica da coinoculação com Azospirillum brasilense e Bradyrhizobium e doses de nitrogênio no feijão-caupi}

RESUMO: A eficiência da fixação biológica de nitrogênio pode ser aumentada pela coinoculação com Azospirillum brasilense e Bradyrhizobium, propiciando maior absorção de água e nutrientes, refletindo em maiores produtividades e permitindo a inserção de culturas não usuais nos sistemas agrícolas na região de Cerrado, como o feijão-caupi (Vigna unguiculata L. Walp.). Desta forma, o objetivo com este estudo foi avaliar a viabilidade técnica e econốmica da produção de feijão-caupi em região de Cerrado, em função de doses de $\mathrm{N}$ e da coinoculação nas sementes com Azospirillum brasilense e Bradyrhizobium. O estudo foi desenvolvido em sistema plantio direto em Selvíria, MS. O delineamento experimental foi em blocos casualizados com quarto repetições, dispostos em esquema factorial 3 x 5, correspondendo a três tipos de inoculação (sem inoculação - testemunha, com duas estirpes de Bradyrhizobium spp., SEMIA 6462 e SEMIA 6463 - a inoculação convencional de feijão-caupi, e estas duas estirpes de Bradyrhizobium sp mais A. brasilense estirpes Ab-V5 e Ab-V6 - a coinoculação); e cinco doses de $\mathrm{N}\left(0,20,40,80\right.$ e $160 \mathrm{~kg} \mathrm{ha}^{-1}$, na forma de ureia, aplicada em cobertura. As seguintes avaliações foram realizadas: produtividade de grãos, custo operational total, custo operacional efetivo, receita bruta, lucro operacional, índice de lucratividade, preço de equilíbrio e produtividade de equilíbrio. A coinoculação com A. brasilense aumentou a produtividade de grãos do feijão-caupi, sendo uma tecnologia tecnicamente e economicamente viável, sem a necessidade de aplicação de fertilizante nitrogenado em cobertura.

Palavras-chave: Vigna unguiculata, bactérias promotoras de crescimento de plantas, fixação biológica de nitrogênio, custo operacional total, lucratividade do produtor 


\section{INTRODUCTION}

Due to its wide genetic variability, tolerance to unfavorable climate conditions, $\mathrm{N}_{2}$ fixation, high yield potential plus an excellent nutritional value, cowpea (Vigna unguiculata L. Walp.) is a potential crop under tropical conditions (Ferreira et al., 2013; Marinho et al., 2017). In Brazil, it is estimated that about 1.5 million hectares of cowpea are cultivated, with an average yield of approximately $520 \mathrm{~kg} \mathrm{ha}^{-1}$ (CONAB, 2018), well below the potential of the crop, which can reach yields greater than $2000 \mathrm{~kg} \mathrm{ha}^{-1}$ (Ferreira et al., 2013; Marinho et al., 2017). One of the factors that contribute to the low average yield of this species is soil fertility management, particularly due to insufficient nitrogen supply (Costa et al., 2014; Marinho et al., 2014).

To obtain high yields, $\mathrm{N}_{2}$ fixation must have maximum efficiency (Rodrigues et al., 2012; Bulegon et al., 2016; Galindo et al., 2017a; Moretti et al., 2018). A better understanding of the rhizobia-legume association under Brazilian Cerrado conditions can provide effective contribution to the $\mathrm{N}$ balance in both soil and plants (Chagas Junior et al., 2010a,b). Considering the main current and potential limitations of Biological Nitrogen Fixation (BNF) in cowpea and the benefits, in various crops, by inoculation with Azospirillum brasilense (free-living diazotrophic bacteria), especially greater root system development and, consequently, higher absorption of water and nutrients, it can be deduced that joint co-inoculation of Bradyrhizobium spp. and A. brasilense can enhance crop performance, in an approach that respects the current demands for agricultural, economic, social and environmental sustainability (Hungria et al., 2013; Galindo et al., 2018a).

In addition, Hungria et al. (2013) reported that these effects promoted by the co-inoculation with plant growthpromoting bacteria (PGPB) and Bradyrhizobium spp. seem to be influenced by specific signals among the bacterial genotypes involved and the host plant genotypes and species. Thus, further research on the response of co-inoculation in legume crops is important for the development of species more responsive to co-inoculation. Also, many legumes are important food for humans and animals worldwide.
In this context, it becomes necessary to conduct more studies to increase BNF efficiency, associating the coinoculation of Bradyrhizobium spp. and A. brasilense in cowpea, allowing better utilization of water and nutrients, to increase cowpea yield in a more sustainable way. However, the literature has few economic studies of co-inoculation with Azospirillum brasilense in cowpea. Given the above, the objective was to evaluate the technical and economic viability of cowpea in the Cerrado region of Brazil, as a function of $\mathrm{N}$ doses and co-inoculation of seeds with Azospirillum brasilense.

\section{Material ANd Methods}

The study was carried out in Selvíria, MS, Brazil (20 22' $\mathrm{S}$ and $51^{\circ} 22^{\prime} \mathrm{W}, 335 \mathrm{~m}$ a.s.l.) on the Education and Research Farm of FE/UNESP. The soil of the experimental area is classified as an Oxisol, which has been cultivated with annual crops for more than 28 years, the last 12 years being under a no-tillage system with wheat, and two corn crops as previous crops. The annual average temperature was $23.5^{\circ} \mathrm{C}$, the average annual rainfall was $1,370 \mathrm{~mm}$ and the mean annual air relative humidity was between 70.0 and $80.0 \%$ (Figure 1).

The experimental design was a randomized block design, with four repetitions, arranged in a $3 \times 5$ factorial scheme, corresponding to three types of inoculation (without inoculation, with two strains of Bradyrhizobium spp., SEMIA 6462 and SEMIA 6463 - the conventional inoculation of cowpea, and these two strains of Bradyrhizobium spp. plus Azospirillum brasilense strains Ab-V5 and Ab-V6 - the coinoculation); and five doses of $\mathrm{N}\left(0,20,40,80\right.$ and $160 \mathrm{~kg} \mathrm{ha}^{-1}$, as urea) applied as topdressing, 15 days after sowing. The plots of the experiment were $5 \mathrm{~m}$ long with seven rows spaced by $0.45 \mathrm{~m}$, and the measurements were taken in the four central rows, excluding $0.5 \mathrm{~m}$ from the extremities.

The herbicides glyphosate ( $\mathrm{N}$ - (phosphonomethyl) glycine) - $1800 \mathrm{~g} \mathrm{ha}^{-1}$ a.i.) and 2,4-D (Dichlorophenoxyacetic acid $-670 \mathrm{~g} 190 \mathrm{ha}^{-1}$ a.i.) were used for the desiccation of the agricultural area. The granulometric analysis presented the

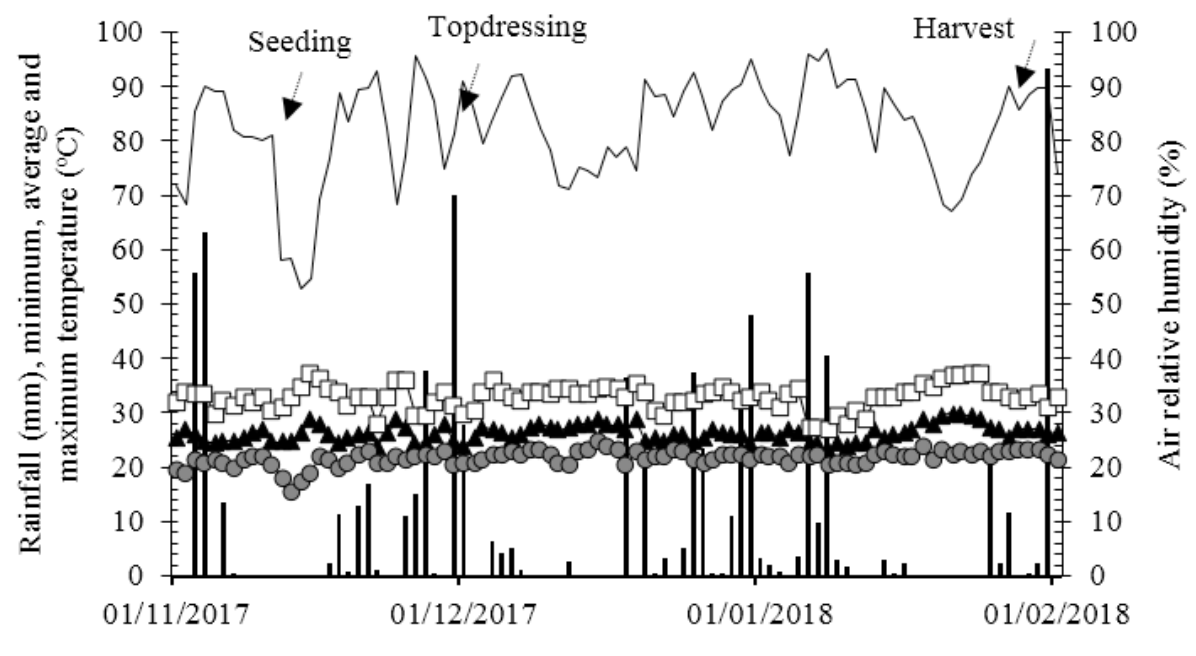

Rainfall $\longrightarrow$ Av. T. $\square-$ Max. T. $\multimap-$ Min. T. $\longrightarrow$ Air Rel. Humi.

Figure 1. Rainfall, air relative humidity (Air Rel. Hum.), and maximum (Max. T.), average (Av. T.), and minimum temperature (Min. T.) obtained from the weather station located on the Education and Research Farm of FE / UNESP during the experiment (November 2017 to February 2018) 
following results: 439, 471 and $90 \mathrm{~g} \mathrm{~kg}^{-1}$ of clay, sand and silt, respectively, at a depth of $0-0.20 \mathrm{~m}$. The chemical attributes of the soil in the $0-0.20 \mathrm{~m}$ layer were determined prior to the cowpea experiment, according to the methodology proposed by Raij et al. (2001). The soil chemical attributes were: P (resin) $=39 \mathrm{mg} \mathrm{dm}^{-3} ; \mathrm{S}_{-} \mathrm{SO}_{4}=30 \mathrm{mg} \mathrm{dm}^{-3}$; organic matter $=22 \mathrm{~g} \mathrm{dm}^{-3}$; $\mathrm{pH}\left(\mathrm{CaCl}_{2}\right)=5.1 ; \mathrm{K}, \mathrm{Ca}, \mathrm{Mg}, \mathrm{H}+\mathrm{Al}$ and $\mathrm{Al}=2.3 ; 31.0 ; 33.0$; 34.0 and $0 \mathrm{mmol}_{\mathrm{c}} \mathrm{dm}^{-3}$, respectively; $\mathrm{Cu}, \mathrm{Fe}, \mathrm{Mn}, \mathrm{Zn}$ (DTPA) $=3.7 ; 25.0 ; 30.1$ and $1.7 \mathrm{mg} \mathrm{dm}^{-3}$, respectively; $\mathrm{B}$ (hot water) $=0.23 \mathrm{mg} \mathrm{dm}^{-3}$, cation exchange capacity $(\mathrm{pH} \mathrm{7.0)}=100.3$ mmol d $\mathrm{dm}^{-3}$ and base saturation $=66.0 \%$. Total $\mathrm{N}$ concentration was equal to $1.04 \mathrm{~g} \mathrm{~kg}^{-1}$ (Determined by the regular Kjeldahl method using a block digester, followed by diffusion with $\mathrm{NaOH}$ (Stevens et al., 2000).

The corn straw (previous crop) was collected at sowing to characterize and estimate the accumulation of nutrients: $77.1 ; 10.4 ; 36.0 ; 30.1 ; 16.4 ; 14.2$ and $3.1 \mathrm{~kg} \mathrm{ha}^{-1}$ of N, P, K, Ca, $\mathrm{Mg}$, S and Si, respectively, and $185.5 ; 201.9 ; 1627.9 ; 948.5$ and $740.4 \mathrm{~g} \mathrm{ha}^{-1}$ of $\mathrm{B}, \mathrm{Cu}, \mathrm{Fe}, \mathrm{Mn}$ and $\mathrm{Zn}$, respectively, and $\mathrm{C}: \mathrm{N}$ ratio of 38.55 .

At sowing, $40 \mathrm{~kg} \mathrm{ha}^{-1}$ of $\mathrm{P}_{2} \mathrm{O}_{5}$ (triple superphosphate) and $40 \mathrm{~kg} \mathrm{ha}^{-1}$ of $\mathrm{K}_{2} \mathrm{O}$ (potassium chloride) were applied by the seeder (Tatu Marchesan Ultra Flex ${ }^{\circledR}$ ), distributed next to and below the seeds, for all treatments, based on the soil analysis, cowpea requirement and the crop history in the area (Andrade Jr. et al., 2002).

The inoculation of cowpea seeds with the bacterium Bradyrhizobium spp. strains SEMIA 6462 and SEMIA 6463 (TotalNitro - Total Biotecnologia ${ }^{\oplus}$, guarantee of $5 \times 10^{9} \mathrm{CFU}$ $\mathrm{mL}^{-1}$ ) and co-inoculation with Azospirillum brasilense strains $\mathrm{Ab}-\mathrm{V} 5$ and Ab-V6 (Azototal - Total Biotecnologia ${ }^{\circledR}$, guarantee of $2 \times 10^{8} \mathrm{CFU} \mathrm{mL} \mathrm{m}^{-1}$ ) were carried out at the dose of $200 \mathrm{~mL}$ of inoculant (liquid) per ha with the aid of a clean mixer for incorporation, one hour before sowing the crop and after treatment of the seeds with insecticide and fungicide. For seed treatment, the fungicides pyraclostrobin + thiophanate-methyl $(6 g+56 g$ of a.i. per $100 \mathrm{~kg}$ of seed) and the insecticide fipronil (62 $\mathrm{g}$ of a.i. per $100 \mathrm{~kg}$ of seed) were used.

Mechanical sowing (seeder Tatu Marchesan Ultra Flex ${ }^{\circledR}$ ) of BRS Tumucumaque cowpea was made on November 10, 2017 , by sowing 12 seeds per meter, and the emergence of seedlings occurred four days after sowing (November 14, 2017). Cowpea was irrigated using a center pivot sprinkling system, with a mean water depth of $14 \mathrm{~mm}$ and an irrigation interval of approximately $72 \mathrm{~h}$. Nitrogen topdressing fertilization was performed between the rows 10 days after emergence (November 24, 2017). The application was done manually, distributing the fertilizer on the soil surface (without incorporation), approximately $10 \mathrm{~cm}$ from the rows, in order to avoid contact of the fertilizer with the plants. After topdressing fertilization, the area was irrigated by sprinkling (depth of 14 $\mathrm{mm}$ ) at night to minimize losses by volatilization of ammonia. The herbicides clethodim ( $96 \mathrm{~g} \mathrm{ha}^{-1}$ of a.i.) and bentazon (576 $\mathrm{g} \mathrm{ha}^{-1}$ of a.i.) were applied for the control of post-emergence weeds on November 25, 2017. Insect control was performed with beta-cyfluthrin $\left(8 \mathrm{~g} \mathrm{ha}^{-1}\right.$ a.i. $)$ and abamectin $\left(9 \mathrm{~g} \mathrm{ha}^{-1}\right.$ a.i. $)$, on November 25, 2017 and December 14, 2017, respectively, and with imidacloprid + beta-cyfluthrin $\left(9 \mathrm{~g} \mathrm{ha}^{-1}\right.$ a.i. $)$ and deltametrin ( $4 \mathrm{~g} \mathrm{ha}^{-1}$ a.i.) on December 1, 2017. In all insecticide applications, vegetable oil (720 $\mathrm{g} \mathrm{ha}^{-1}$ of a.i.) was added as adjuvant in the insecticide mixture. Harvest was carried out on January 30, 2018 (76 days after emergence).

Grain yield was determined by harvesting the plants contained in the usable area of each plot (four central rows, excluding $0.5 \mathrm{~m}$ from the extremities). After harvest, the grains were quantified in $60-\mathrm{kg}$ sacks $\mathrm{ha}^{-1}$ and corrected to $13.0 \%$ moisture (wet basis).

Data were submitted to analysis of variance (F test). When a significant result was verified by the $F$ test ( $p \leq 0.01$ and $p$ $\leq 0.05)$, the Tukey test ( $\mathrm{p} \leq 0.05$ ) was used for comparison of inoculation means and polynomial regression was fitted for the $\mathrm{N}$ doses using PROC REG procedure of SAS program (SAS Institute, 2015).

Economic analysis was performed using the structure based on the Total Operating Cost (TOC) of production, used by the Instituto de Economia Agrícola (IEA), according to Matsunaga et al. (1976), which consists of the sum of expense costs: operations, inputs (fertilizers, seeds, pesticides, etc.), labor, machinery and irrigation, called Effective Operating Cost (EOC). Besides TOC, the study considered other expenses and interest rates, representing 5.0\% of EOC (Matsunaga et al., 1976), thus resulting in the total operating cost (TOC), which was extrapolated to one hectare. This methodology has been previously used in several studies on economic evaluation of crops [Kappes et al. (2015), Portugal et al. (2016), Galindo et al. (2017b) and Galindo et al. (2018b)].

The profits of the treatments were determined through profitability analyses according to Martin et al. (1998). For that, the following variables were determined: Gross Revenue (GR) (in $\mathrm{R} \$$ ), as the product between produced quantity (in number of 60-kg sacks) and mean selling price (in R\$); Operating Profit (OP), as the difference between GR and TOC; Profitability Index (PI), understood as the ratio between OP and GR, in percentage, Equilibrium Price (EP), given a certain total operating production cost, as the minimum price calculated to cover this cost, considering the average yield obtained; and Equilibrium Yield (EY), given a certain total operating production cost, as the minimum yield to cover this cost, considering the average price paid to the farmer.

The analysis considered the prices practiced in commercial crops in the region of Selvíria, MS, Brazil, based on the mean of the last three agricultural years. Simulations were made as if each treatment of the experiment represented commercial crops. To facilitate the discussion, yield values were converted to $60-\mathrm{kg}$ sacks, because this is the basic marketing unit used by the local farmers. The cost of the cowpea sack for the municipality of Selvíria, MS, Brazil, was R 70.00 per unit produced. The price paid by the farmer was $\mathrm{R} \$ 1.85 \mathrm{~kg}^{-1}$ for urea. For the inoculum with Bradyrhizobium spp. and Azospirillum brasilense, the expenditure was approximately $\mathrm{R} \$ 10.00$ per dose (each inoculant), and two doses of each inoculant were used per hectare.

\section{Results AND Discussion}

The interaction between $\mathrm{N}$ doses and inoculations was significant for cowpea grain yield (Table 1). In the absence of nitrogen fertilization, and with application of 40 and $160 \mathrm{~kg} \mathrm{ha}^{-1}$ 
of $\mathrm{N}$, the co-inoculation with $A$. brasilense resulted in higher grain yield compared to the control treatment (Figure 2), increases of 11.59 and $10.2860-\mathrm{kg}$ sacks ha ${ }^{-1}$, equivalent to 45.1 and $43.5 \%$, respectively. With application of $80 \mathrm{~kg} \mathrm{ha}^{-1}$, the coinoculation promoted higher yield compared to conventional inoculation with Bradyrhizobium spp., an increase of $1560-\mathrm{kg}$ sacks ha-1 ${ }^{-1}$ equivalent to $24.1 \%$. In the mean values, the coinoculation with $A$. brasilense increased the yield of cowpea by 6.91 and $8.6860-\mathrm{kg}$ sacks ha ${ }^{-1}$, compared to conventional inoculation and control treatment, increases equivalent to 25.2 and $33.9 \%$, respectively (Figure 2 ).

According to Bárbaro et al. (2009), the literature reports that bacteria called PGPB (plant growth-promoting bacteria), such as $A$. brasilense, can act in association with rhizobia and leguminous species, promoting increments in plant growth and grain yield, in biologically fixed $\mathrm{N}$, and improvements in the

Table 1. Cowpea grain yield as affected by $\mathrm{N}$ doses and inoculation method with Bradyrhizobium spp. or Bradyrhizobium spp. and A. brasilense

\begin{tabular}{lc}
\hline N doses & $\begin{array}{c}\text { Grain yield } \\
\text { 60-kg sack ha-1 }\end{array}$ \\
0 & \\
20 & 30.28 \\
40 & 29.23 \\
80 & 30.73 \\
160 & 27.81 \\
\hline Inoculation & 27.46 \\
Without & \\
Bradyrhizobium spp. & 25.62 \\
Bradyrhizobium spp. + A. brasilense & 27.39 \\
LSD (0.05) & 34.30 \\
Overall Mean & 4.45 \\
CV (0.05) & 29.10 \\
\hline F Test & $19.87 \%$ \\
\hline Doses - D & \\
Inoculation - I & $0.757^{\text {ns }}$ \\
D xl & $12.569^{* *}$ \\
\hline
\end{tabular}

${ }^{* *}$ and ${ }^{*}$ Significant at $\mathrm{p}<0.01$ and $0.01<\mathrm{p}<0.05$, respectively; LSD - Least significant difference

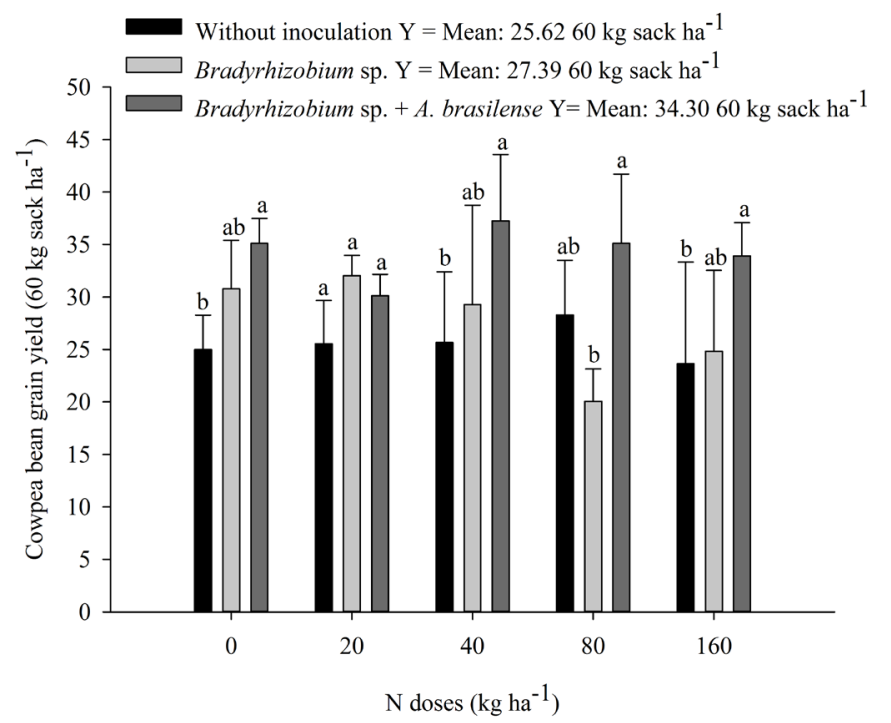

The letters correspond to a significant difference at $\mathrm{p} \leq 0.05$. Error bars indicate the standard deviation of the mean $(\mathrm{n}=4)$

Figure 2. Cowpea grain yield as a function of inoculation methods with Bradyrhizobium spp. or Bradyrhizobium spp. and $A$. brasilense for each $\mathrm{N}$ doses use of $\mathrm{N}$ obtained by the plant through symbiosis with rhizobia, corroborating the results observed in the present study.

These effects can be due to various mechanisms, including early BNF of the nodules, increases in nodule dry matter, promotion of the occurrence of heterologous nodulation through the increase in the formation of root hairs and secondary roots, increase in the sites of infection, inhibition of pathogens and production of phytohormones and influences on dry matter partition among roots and shoots (Bárbaro et al., 2009; Galindo et al., 2018a). Furthermore, as observed by Hungria et al. (2013), these effects promoted by coinoculation with PGPB and rhizobia seem to be influenced by specific signals between bacterial genotypes and the plant host genotype. Thus, further research on the response of coinoculation as a function of genotypes and species is important for the development of more-responsive genotypes.

Although there was no adjustment to the applied $\mathrm{N}$ doses, there was a numerical reduction in grain yield in the absence of nitrogen fertilization and with application of the highest $\mathrm{N}$ doses (80 and $160 \mathrm{~kg} \mathrm{ha}^{-1}$ ), especially when the conventional inoculation with Bradyrhizobium spp. was performed, partially agreeing with Martins et al. (2013), who studied the application of $\mathrm{N}$ doses in topdressing $(0,35,70,105,140 \mathrm{~kg}$ $\mathrm{ha}^{-1}$ ) and inoculation with Bradyrhizobium spp. strain INPA $0311 \mathrm{~B}$ and verified reduction in dry matter of nodules and cowpea grain yield with increasing $\mathrm{N}$ doses. According to Brito et al. (2009), 93\% of $\mathrm{N}$ accumulated in cowpea comes from symbiotic fixation, which demonstrates the importance of BNF in cowpea, and the need for genetic improvement of the genotypes, associating the strains with optimal specificity to the process, making it possible to increase and popularize cowpea cultivation throughout Brazil.

Similar results in legumes were obtained by Hungria et al. (2013), who concluded that co-inoculation with $B$. japonicum $+A$. brasilense in soybean and common bean ( $R$. tropici $+A$. brasilense) increased grain yield in soybean by $14.1 \%$ (compared to control - without inoculation) and $6.4 \%$ (compared to traditional inoculation with symbiotic bacteria), and in common beans by $19.6 \%$ (compared to control) and $14.7 \%$ (compared to traditional inoculation), respectively. Galindo et al. (2017a) verified an increase in the number of pods per plant, mass of 100 grains and soybean grain yield with co-inoculation with $A$. brasilense, with an increase in grain yield of $11.2 \%$ and an increase of $14.4 \%$ in operational profit. Studying co-inoculation of B. japonicum and $A$. brasilense associated with the use of Co and Mo in the seeds, Galindo et al. (2018a), verified an increase in grain yield (18.1\%) compared to conventional inoculation, B. japonicum only, with an increase of $20.4 \%$ in operational profit. Souza \& Ferreira (2017), observed higher common bean grain yield with co-inoculation of $R$. tropici and A. brasilense compared to $\mathrm{N}$-fertilizer application (increase of $5 \%$ ) and compared to conventional inoculation with $R$. tropici (increase of 26\%).

The aforementioned positive results, together with the results obtained in the present study, highlight the importance of new studies of co-inoculation with A. brasilense in legumes, especially in crops such as cowpea, for which research is still scarce. The average yield obtained, regardless of the treatment 
(29.10 60-kg sacks ha-1) was approximately 3.3 times higher than the national average $\left(8.760-\mathrm{kg}\right.$ sacks ha ${ }^{-1}$, Table 1$)$ (CONAB, 2018), elucidating the great potential of this crop in the Cerrado region of Brazil.

The Total Operating Cost (TOC) structure model, Table 2, was used in all treatments. Initial investments with soil tillage and liming were not considered in this study, since these practices were not performed, because the area had been under no-tillage system for more than 10 years when the experiment was initiated, contributing to the reduction of initial costs of crop planting.

The Effective Operating Cost (EOC), composed of expenses with operations and inputs, was equal to $\mathrm{R} \$ 1,552.96 \mathrm{ha}^{-1}$ and the Total Operating Cost (TOC) corresponded to R $\$ 1,681.08$ $\mathrm{ha}^{-1}$. In the EOC, the top three expenses are irrigation (14.5\%), agricultural chemicals (22.7\%) and seeds (21.4\%) (Table 2).

In general, the highest TOC expenses were mechanized operations $(24.9 \%)$, followed by agricultural chemicals $(21.0 \%)$ (Table 2$)$. It is worth pointing out that, with the utilization of inoculation with Bradyrhizobium spp. and coinoculation with $A$. brasilense, the percentage of expenses increases in relation to the TOC. However, the cost with these inoculations are low, representing only 1.2 and $2.3 \%$ of the TOC, respectively.

For TOC and cowpea yield of the treatments (Table 3 ), the highest TOC value occurred in treatments with A. brasilense co-inoculation with application of $160 \mathrm{~kg} \mathrm{ha}^{-1}$ of $\mathrm{N}$. On the other hand, the lowest TOC value corresponds to treatments without both inoculation and $\mathrm{N}$ fertilization. However, it should be highlighted that the highest cowpea yields were obtained when A. brasilense was co-inoculated (Table 1), especially with the application of $40 \mathrm{~kg} \mathrm{ha}^{-1}$ of $\mathrm{N}$ and absence of nitrogen fertilization, which promoted the highest yields obtained (37.26 and 35.10 60-kg sacks ha-1, respectively).

According to Bashan \& Bashan (2010), this increase in grain yield due to the inoculation with bacteria of the genus Azospirillum, in crops of agronomic interest, results from the stimulus to plant growth by multiple mechanisms, including the synthesis of phytohormones (auxin, cytokinin and gibberellin), improvement in $\mathrm{N}$ nutrition, enhancement in leaf photosynthetic variables, attenuation/minimization of stress and biological control of some pathogenic agents.

It is verified that with a constant price of cowpea, the gross revenues of the treatments follow the same trend of the yields (Table 3), i.e., increments in revenue occur because of the increments in grain yield. This result is consistent with that of Galindo et al. (2017b), who claimed that yield is a primordial factor to guarantee good profitability to the producer. Also according to Galindo et al. (2017b), even in regions where the producer obtains good prices in the marketing of grains, if the yield is low, the profitability is compromised. Thus, investment in management practices, such as balanced fertilization and

Table 2. Total operating cost (TOC, $\left.\mathrm{R} \$ \mathrm{ha}^{-1}\right)$ structure model of cowpea for the treatment control $\left(0 \mathrm{~kg}^{-1} \mathrm{~N}\right.$ in topdressing), and without inoculation with Bradyrhizobium spp. and A. brasilense per hectare

\begin{tabular}{|c|c|c|c|c|}
\hline \multirow[t]{2}{*}{ Description } & \multirow[t]{2}{*}{ Unit' } & \multirow[t]{2}{*}{ Amount ${ }^{2}$} & Unitary value & Total value \\
\hline & & & \multicolumn{2}{|c|}{ (R\$) } \\
\hline \multicolumn{5}{|l|}{ A. Operations } \\
\hline Desiccation & $1.0 \mathrm{HM}$ & 0.50 & 85.00 & 42.50 \\
\hline Hoeing (triton) & $1.0 \mathrm{HM}$ & 0.50 & 85.00 & 42.50 \\
\hline Seeding & $1.0 \mathrm{HM}$ & 1.00 & 110.00 & 110.00 \\
\hline Pulverization & $3.0 \mathrm{HM}$ & 0.60 & 85.00 & 153.00 \\
\hline Topdressing & $0.0 \mathrm{HM}$ & 0.50 & 85.00 & 0.00 \\
\hline Harvest & $1.0 \mathrm{HM}$ & 0.60 & 118.00 & 70.80 \\
\hline Irrigation (pivot) & $1.0 \mathrm{~mm}$ & 90.00 & 2.50 & 225.00 \\
\hline Subtotal A & & & & 643.80 \\
\hline \multicolumn{5}{|l|}{ B - Agricultural Input } \\
\hline Triple superphosphate & $1.0 \mathrm{~T}$ & 0.09 & $1,100.00$ & 97.78 \\
\hline Potassium chloride & $1.0 \mathrm{~T}$ & 0.07 & $1,900.00$ & 126.67 \\
\hline Urea & $1.0 \mathrm{~T}$ & 0.00 & $1,850.00$ & 0.00 \\
\hline Bradyrhizobium spp. inoculant & 1.0 Dose $(100 \mathrm{~mL})$ & 0.00 & 10.00 & 0.00 \\
\hline A. brasilense inoculant & 1.0 Dose $(100 \mathrm{~mL})$ & 0.00 & 10.00 & 0.00 \\
\hline Cowpea BRS Tumucumaque & $1.0 \mathrm{sc} 50 \mathrm{~kg}$ & 1.07 & 310.00 & 331.70 \\
\hline Herbicida glyphosate & $1.0 \mathrm{~L}$ & 4.00 & 14.51 & 58.04 \\
\hline Herbicida 2,4-D & $1.0 \mathrm{~L}$ & 1.00 & 13.24 & 13.24 \\
\hline Herbicide Clethodim & $1.0 \mathrm{~L}$ & 0.40 & 91.60 & 36.64 \\
\hline Herbicide Bentazon & $1.0 \mathrm{~L}$ & 1.20 & 66.20 & 79.44 \\
\hline Insecticide Beta-cyfluthrin & $2.0 \mathrm{~L}$ & 0.15 & 103.00 & 30.90 \\
\hline Insecticide Abamectin & $2.0 \mathrm{~L}$ & 0.50 & 23.00 & 23.00 \\
\hline Insecticide Imidacloprid + Beta-cyfluthrin & $1.0 \mathrm{~L}$ & 0.75 & 57.00 & 42.75 \\
\hline Insecticide Deltametrin & $1.0 \mathrm{~L}$ & 0.15 & 80.00 & 12.00 \\
\hline Fungicide seed treatment pyraclostrobin + thiophanate-methyl + fipronil & $1.0 \mathrm{~L}$ & 0.11 & 350.00 & 37.33 \\
\hline Vegetable oil adjuvant & $3.0 \mathrm{~L}$ & 0.78 & 8.41 & 19.68 \\
\hline Subtotal B & & & & 909.16 \\
\hline Effective operating costs (EOC) & & & & $1,552.96$ \\
\hline Other expenses & & & & 77.65 \\
\hline Interest cost & & & & 50.47 \\
\hline Total operating cost (TOC) & & & & $1,681.08$ \\
\hline
\end{tabular}

${ }^{1} \mathrm{HM}$ - Hour machine; sc - Sack; 2017 and 2018 average exchange rate: $\mathrm{R} \$ 3.51=\mathrm{U} \$ 1.00$

${ }^{2} \mathrm{Amount}$ refers to the quantity in $\mathrm{HM}$ of operations or the unit quantity of a given agricultural input 
Table 3. Total operating cost (TOC), grain yield (YIELD), gross revenue (GR), operating profit (OP), profitability index (PI), equilibrium price (EP) and equilibrium yield (EY) of Cowpea affected by nitrogen doses with or without inoculation with Bradyrhizobium spp. or co-inoculation with Bradyrhizobium spp. and Azospirillum brasilense

\begin{tabular}{|c|c|c|c|c|c|c|c|}
\hline $\begin{array}{l}\text { Doses } \\
\left(\mathrm{kg} \mathrm{ha}^{-1}\right)\end{array}$ & $\begin{array}{l}\text { TOC } \\
\text { (R\$) }\end{array}$ & $\begin{array}{c}\text { Yield } \\
\left(60-\mathrm{kg} \mathrm{ha}^{-1} \mathrm{sc}\right)\end{array}$ & GR & $\mathrm{OP}$ & $\begin{array}{l}\text { PI } \\
(\%)\end{array}$ & $\begin{array}{c}\text { EP } \\
\left(\text { R\$ sc }^{-1}\right)\end{array}$ & $\begin{array}{c}E Y \\
\left(60-k^{\prime} h^{-1} \mathrm{sc}\right)\end{array}$ \\
\hline \multicolumn{8}{|c|}{ Without inoculation } \\
\hline 0 & 1681.08 & 24.98 & $1,748.60$ & 67.52 & 3.86 & 67.30 & 24.02 \\
\hline 20 & 1816.01 & 25.54 & $1,787.80$ & -28.21 & -1.58 & 71.10 & 25.94 \\
\hline 40 & 1905.08 & 25.67 & $1,796.90$ & -108.18 & -6.02 & 74.21 & 27.22 \\
\hline 80 & 2083.10 & 28.29 & 1.980 .30 & -102.80 & -5.19 & 73.63 & 29.76 \\
\hline 160 & 2439.14 & 23.64 & 1.654 .80 & -784.34 & -47.40 & 103.18 & 34.84 \\
\hline Mean & 1984.88 & 25.62 & $1,793.68$ & -191.20 & -11.27 & 77.89 & 28.36 \\
\hline \multicolumn{8}{|c|}{ Bradyrhizobium spp. } \\
\hline 0 & 1702.73 & 30.77 & $2,153.90$ & 451.17 & 20.95 & 55.34 & 24.32 \\
\hline 20 & 1837.66 & 32.03 & $2,242.10$ & 404.44 & 18.04 & 57.37 & 26.25 \\
\hline 40 & 1926.73 & 29.27 & $2,048.90$ & 122.17 & 5.96 & 65.83 & 27.52 \\
\hline 80 & 2104.75 & 20.04 & $1,402.80$ & -701.95 & -50.04 & 105.03 & 30.07 \\
\hline 160 & 2460.79 & 24.84 & $1,738.10$ & -722.69 & -41.58 & 99.11 & 35.15 \\
\hline Mean & 2006.53 & 27.39 & $1,917.16$ & -89.37 & -9.33 & 76.53 & 28.66 \\
\hline \multicolumn{8}{|c|}{ Bradyrhizobium spp. and $A$. brasilense } \\
\hline 0 & 1724.38 & 35.10 & $2,457.00$ & 732.62 & 29.82 & 49.13 & 24.63 \\
\hline 20 & 1859.31 & 30.12 & 2.10840 & 249.09 & 11.81 & 61.73 & 26.56 \\
\hline 40 & 1948.38 & 37.26 & 2608.20 & 659.82 & 25.30 & 5229 & 27.83 \\
\hline 80 & 2126.40 & 35.10 & 2457.00 & 330.60 & 13.46 & 60.58 & 30.38 \\
\hline 160 & 2482.44 & 33.92 & $2,374.40$ & -108.04 & -4.55 & 73.19 & 35.46 \\
\hline Mean & 2028.18 & 34.05 & $2,401.00$ & 372.82 & 15.17 & 59.38 & 28.97 \\
\hline
\end{tabular}

Average cowpea bean trading price R $\$ 70.00$ per 60-kg sack according to IBRAFE (2018); 2017 and 2018 average exchange rate: R $\$ 3.51=$ U $\$ 1.00$

inoculation techniques, increases grain yield and the gross margin of the crops.

For the values referring to operating profit (Table 3), higher $\mathrm{N}$ doses lower the OP, except for $40 \mathrm{~kg} \mathrm{ha}^{-1}$. In the absence of inoculation, the OP was positive only in the absence of nitrogen fertilization, whereas when the conventional inoculation with Bradyrhizobium spp. was carried out, the applications of 20 and $40 \mathrm{~kg} \mathrm{ha}^{-1}$ of $\mathrm{N}$ promoted positive profitability, and with the co-inoculation with $A$. brasilense, the applications of 20,40 and $80 \mathrm{~kg} \mathrm{ha}^{-1}$ promoted positive profitability, which shows that the relationship between the benefit of conventional inoculation and co-inoculation on cowpea grain yield in relation to the cost of these technologies is positive, generating profitability.

The highest $\mathrm{OP}$ was verified by the co-inoculation with $A$. brasilense in the absence of nitrogen fertilization ( $\mathrm{R} \$ 732.62$ ). In the absence of inoculation with Bradyrhizobium spp. and co-inoculation with $A$. brasilense, which would cause reduction of costs, with possibility of increase in OP, if good yields were obtained, the cowpea crop would be viable without $\mathrm{N}$ fertilization, but with reductions of $\mathrm{R} \$ 383.65$ and $\mathrm{R} \$ 665.10$ $\mathrm{ha}^{-1}$ in the profit, which are equivalent to 85.0 and $91.0 \%$ in the profitability, compared to the conventional inoculation and co-inoculation, respectively.

The co-inoculation propitiated $\mathrm{R} \$ 281.45 \mathrm{ha}^{-1}$ higher profit compared with conventional inoculation in the absence of $\mathrm{N}$ fertilization, which is equivalent to an increment of $62.4 \%$, which demonstrates the benefit of this technique from the economic point of view. As evidenced for OP, the treatment leading to highest PI was co-inoculation with A. brasilense in the seeds without $\mathrm{N}$ fertilization (29.82\%), which was 42.3 and $72.5 \%$ superior to that of the treatments inoculated with Bradyrhizobium spp. and not inoculated, respectively (Table 3 ), reinforcing the importance of co-inoculation with $A$. brasilense to obtain superior yields and, consequently, higher financial return.
Regarding the equilibrium price, that is, the price that must be paid for the $60-\mathrm{kg}$ sack of cowpea so that there is no financial loss to the farmer, the values follow the trend of TOC, that is, the higher the TOC as a function of treatments, the higher the price paid to the farmer in order to avoid losses of production. Thus, with the increase of $\mathrm{N}$ doses applied and with the use of co-inoculation, the equilibrium price is higher (Table 3 ).

The equilibrium yield, that is, the grain yield that must be obtained so that the farmers have no financial loss, considering the price paid in 60-kg sacks of cowpea and the production cost of the crop, follows the inverse trend of the OP and PI. The higher the cost with a given treatment, the higher the equilibrium yield; consequently, the higher EY was obtained with nitrogen fertilization (Table 3 ).

The economic results obtained agree with Hungria et al. (2013), who concluded that microbial inoculants are very inexpensive and can save billions of dollars per year with BNF. Therefore, the potential of co-inoculation with $A$. brasilense in the development and yield of cowpea is very high, especially for being a technique with low cost and investment, of easy application and use. Besides the following cowpea characteristics: genetic variability; tolerance to adverse climatic conditions; $\mathrm{N}_{2}$ fixation potential; high yield potential; excellent nutritional value and short cycle, being earlier than the common bean (cycle varying from 65 to 75 days from sowing to harvest, on average). Cowpea has been studied and gained prominence in scientific research (Chagas Junior et al., 2010a,b; Marinho et al., 2017), being a crop with potential for expansion in several agricultural areas worldwide, such as the Brazilian Cerrado.

The results of the present study indicated that there is an opportunity to reduce $\mathrm{N}$ fertilizer inputs while increasing cowpea yields by co-inoculation with Bradyrhizobium spp. and Azospirillum brasilense. These are important considerations in Brazil, where resources are limited and there is a need to improve agricultural yield and the economic and environmental 
sustainability, elucidating the great potential of this crop in the Cerrado of Brazil.

\section{Conclusions}

1. Co-inoculation with Bradyrhizobium spp. and Azospirillum brasilense increases cowpea grain yield, even when associated with $\mathrm{N}$ doses applied in topdressing.

2. The co-inoculation technique with these bacteria provides greater technical and economic viability with cowpea, being a recommended technology, without the need to apply $\mathrm{N}$ fertilizers in topdressing.

\section{Literature Cited}

Andrade Júnior, A. S. de; Santos, A. A. dos; Athayde Sobrinho, C.; Bastos, E. A.; Melo, F. de B.; Viana, F. M. P.; Freire Filho, F. R.; Carneiro, J. da S.; Rocha, M. de M.; Cardoso, M. J.; Silva, P. H. S. da.; Ribeiro, V. Q. Cultivo de feijão-caupi. Teresina: Embrapa Meio-Norte, 2002. 108p.

Bárbaro, I. M.; Centurio, M. A. P. da C.; Gavioli, E. A.; Sarti, D. G. P.; Bárbaro Júnior, L. S.; Ticelli, M.; Miguel, F. B. Análise de cultivares de soja em resposta à inoculação e aplicação de cobalto e molibdênio. Revista Ceres, v.56, p.342-349, 2009. https://doi. org/10.5747/ca.2009.v05.n1.a0040

Bashan, Y.; Bashan, L. E. de. How the plant growth-promoting bacterium Azospirillum promotes plant growth: A critical assessment. Advances in Agronomy, v.108, p.77-136, 2010. https:// doi.org/10.1016/S0065-2113(10)08002-8

Brito, M. M. P.; Muraoka, T.; Silva, E. C. Marcha de absorção do nitrogênio do solo, do fertilizante e da fixação simbiótica em feijão-caupi [Vigna unguiculata (L.) Walp.] e feijão-comum (Phaseolus vulgaris L.) determinada com uso de ${ }^{15} \mathrm{~N}$. Revista Brasileira de Ciência do Solo, v.33, p.895-905, 2009. https://doi. org/10.1590/S0100-06832009000400014

Bulegon, L. G.; Rampim, L.; Klein, J.; Kestring, D.; Guimarães, V. F.; Battistus, A. G.; Inagaki, A. M. Componentes de produção e produtividade da cultura da soja submetida à inoculação de Bradyrhizobium e Azospirillum. Terra Latinoamericana, v.34, p.169-176, 2016.

Chagas Junior, A. F.; Oliveira, L. A.; Oliveira, A. N. Caracterização fenotípica de rizóbio nativos isolados de solos da Amazônia e eficiência simbiótica em feijão caupi. Acta Scientiarum. Agronomy, v.32, p.161-169, 2010a. https://doi.org/10.4025/ actasciagron.v32i1.900

Chagas Junior, A. F.; Rahmeirer, W.; Fidelis, R. R.; Santos, G. R.; Chagas, L. F. B. Eficiência agronômica de estirpes de rizóbio inoculadas em feijão-caupi no Cerrado, Gurupi - TO. Revista Ciência Agronômica, v.41, p.709-714, 2010b. https://doi. org/10.1590/S1806-66902010000400027

CONAB - Companhia Nacional de Abastecimento. Acompanhamento da safra brasileira de grãos - Novembro/2018. Brasília: CONAB. Available on: <http://www.conab.gov.br/conteudos.php?a=1253>. Accessed on: Nov. 2018.

Costa, E. M.; Nóbrega, R. S. A.; Silva, A. F. T.; Ferreira, L. M. V.; Nóbrega, J. C. A.; Moreira, F. M. S. Resposta de duas cultivares de feijão-caupi à inoculação com bactérias fixadoras de nitrogênio em ambiente protegido. Revista Brasileira de Ciências Agrárias, v.9, p.489-494, 2014. https://doi.org/10.5039/agraria.v9i4a3590
Ferreira, L. V. M.; Nóbrega, R. S. A.; Nóbrega, J. C. A.; Aguiar, F. L.; Moreira, F. M. S.; Pacheco, L. P. Biological nitrogen fixation in production of Vigna unguiculata (L.) Walp, family farming in Piauí, Brazil. Journal of Agricultural Science, v.5, p.153-160, 2013. https://doi.org/10.5539/jas.v5n4p153

Galindo, F. S.; Teixeira Filho, M. C. M.; Buzetti, S.; Ludkiewicz, M. G. Z.; Rosa, P. A. L.; Tritapepe, C. A. Technical and economic viability of co-inoculation with Azospirillum brasilense in soybean cultivars in the Cerrado. Revista Brasileira de Engenharia Agrícola e Ambiental, v.22, p.51-56, 2018a. https://doi.org/10.1590/18071929/agriambi.v22n1p51-56

Galindo, F. S.; Teixeira Filho, M. C. M.; Buzetti, S.; Santini, J. M. K.; Ludkiewicz, M. G. Z.; Baggio, G. Modes of application of cobalt, molybdenum and Azospirillum brasilense on soybean yield and profitability. Revista Brasileira de Engenharia Agrícola e Ambiental, v.21, p.180-185, 2017a. https://doi.org/10.1590/18071929/agriambi.v21n3p180-185

Galindo, F. S.; Teixeira Filho, M. C. M.; Tarsitano, M. A. A.; Buzetti, S.; Santini, J. M. K.; Ludkiewicz, M. G. Z.; Alves, C. J.; Arf O. Economic analysis of maize inoculated with Azospirillum brasilense associated with nitrogen sources and doses. Semina: Ciências Agrárias, v.38, p.1749-1764, 2017b. https://doi. org/10.5433/1679-0359.2017v38n4p1749

Galindo, F. S.; Teixeira Filho, M. C. M.; Tarsitano, M. A. A.; Buzetti, S.; Santini, J. M. K.; Ludkiewicz, M. G. Z.; Alves, C. J. Technical and economic feasibility of irrigated wheat as a function of nitrogen doses, sources, and inoculation with Azospirillum brasilense. Semina: Ciências Agrárias, v.39, p.51-56, 2018b. https:// doi.org/10.5433/1679-0359.2018v39n1p51

Hungria, M.; Nogueira, M. A.; Araujo, R. S. Co-inoculation of soybeans and common beans with rhizobia and azospirilla: Strategies to improve sustainability. Biology \& Fertility of Soils, v.49, p.791-801, 2013. https://doi.org/10.1007/s00374-012-0771-5

IBRAFE - Instituto Brasileiro do Feijão e Pulses. Preço Nacional do Feijão. Available on: <http:// http://www.ibrafe.org/>. Accessed on: Nov. 2018.

Kappes, C.; Gitti, D. C.; Arf, O.; Andrade, J. A. C.; Tarsitano, M. A. A. Análise econômica do milho em sucessão a diferentes adubos verdes, manejos do solo e doses de nitrogênio. Bioscience Journal, v.31, p.55-64, 2015. https://doi.org/10.14393/BJv31n1a2015-18092

Marinho, R. C. N.; Ferreira, L. V. M.; Silva, A. F; Martins, L. M. V.; Nóbrega, R. S. A.; Fernandes-Júnior, P. I. Symbiotic and agronomic efficiency of new cowpea rhizobia from Brazilian Semi-Arid. Bragantia, v.76, p.273-281, 2017. https://doi.org/10.1590/1678-4499.003

Marinho, R. C. N.; Nóbrega, R. S. A.; Zilli, J. E.; Xavier, G. R.; Santos, C. A. F.; Aidar, S. T.; Martins, L. M. V.; Fernandes Júnior, P. I. Field performance of new cowpea cultivars inoculated with efficient nitrogen-fixing rhizobial strains in the Brazilian Semiarid. Pesquisa Agropecuária Brasileira, v.49, p.395-402, 2014. https:// doi.org/10.1590/S0100-204X2014000500009

Martin, N. B.; Serra, R.; Oliveira, M. D. M.; Ângelo, J. A.; Okawa, H. Sistema integrado de custos agropecuários - CUSTAGRI. Informações Econômicas, v.28, p.7-28, 1998.

Martins, R. N. L.; Nóbrega, R. S. A.; Silva, A. F. T.; Nóbrega, J. C. A.; Amaral, F. H. C.; Costa, E. M.; Lustosa Filho, J. F.; Martins, L. V. Nitrogênio e micronutrientes na produção de grãos de feijão-caupi inoculado. Semina: Ciências Agrárias, v.34, p.1577-1586, 2013. https://doi.org/10.5433/1679-0359.2013v34n4p1577 
Matsunaga, M.; Bemelmans, P. F.; Toledo, P. N. E.; Dulley, R. D.; Okawa, H.; Pedroso, I. A. Metodologia de custo de produção utilizada pelo IEA. Agricultura em São Paulo, v.23, p.123- 139, 1976.

Moretti, L. G.; Lazarini, E.; Bossolani, J. W.; Parente, T. L.; Caioni, S.; Araujo, R. S.; Hungria, M. Can additional inoculations increase soybean nodulation and grain yield? Agronomy Journal, v.110, p.715-721, 2018. https://doi.org/10.2134/agronj2017.09.0540

Portugal, J. R.; Tarsitano, M. A. A.; Peres, A. R.; Arf, O.; Gitti, D. C. Organic and mineral fertilizer application in upland rice irrigated by sprinkler irrigation: Economic analysis. Científica, v.44, p.146155, 2016. https://doi.org/10.15361/1984-5529.2016v44n2p146-155

Raij, B. van; Andrade, J. C.; Cantarella, H.; Quaggio, J. A. Análise química para avaliação da fertilidade de solos tropicais. Campinas: Instituto Agronômico de Campinas, 2001. 285p.
Rodrigues, A. C.; Antunes, J. E. L.; Medeiros, V. V. de; Barros, B. G. de F.; Figueiredo, M. do V. B. Resposta da co-inoculação de bactérias promotoras de crescimento em plantas e Bradyrhizobium sp. em caupi. Bioscience Journal, v.28, p.196-202, 2012.

SAS Institute - Statistical Analysis System. Procedure guide for personal computers. version 9.4. Cary: SAS Institute, 2015.

Souza, J. E. B.; Ferreira, E. P. B. Improving sustainability of common bean production systems by co-inoculating rhizobia and azospirilla. Agriculture, Ecosystems \& Environment, v.37, p.250257, 2017. https://doi.org/10.1016/j.agee.2016.12.040

Stevens, W. B.; Mulvaney, R. L.; Khan, S. A.; Hoeft, R. G. Improved diffusion methods for nitrogen and ${ }^{15}$ nitrogen analysis of Kjeldahl digests. Journal of AOAC International, v.83, p.10391046, 2000. 